\title{
Infeksi HIV pada bayi
}

\author{
Boris Januar, Sjawitri P Siregar
}

\begin{abstract}
Seorang bayi berusia 5 bulan didiagnosis infeksi HIV dari ibu dengan HIV positif. Diagnosis ditegakkan dengan pemeriksaan PCR RNA HIV satu kali, dan ditunjang dengan pemeriksaan klinis serta pemeriksaan serologi terhadap HIV. Seharusnya untuk menegakkan diagnosis infeksi HIV, kita harus melakukan pemeriksaan virologi HIV paling sedikit dua kali dalam waktu yang berbeda. Sangat disayangkan, tidak ada obat antiretroviral yang dapat diberikan untuk mencegah transmisi penularan HIV dari ibu ke bayi baik yang diberikan sebelum maupun sesudah bayi lahir. Hal ini karena tidak adanya informasi dari orang tua. Bayi dengan infeksi HIV harus segera mendapat imunisasi dengan vaksin inactivacted, sedang pemberian vaksin hidup tidak dapat diberikan sampai diketahui status imunologis bayi tersebut. Pengobatan antiretroviral kombinasi harus diberikan segera pada bayi di bawah 12 bulan begitu diagnosis ditegakkan. Konseling keluarga dan kunjungan berkala penting dilakukan untuk memantau progesifitas penyakit, status imunologis, dan ketaatan pengobatan, hal ini untuk mencegah resisten terhadap pengobatan.
\end{abstract}

Kata kunci: HIV, AIDS, viral load, PCR DNA HIV

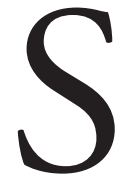

ejak dua puluh tahun yang lalu infeksi Human Immunodeficiency Virus 1 (HIV-1) dan acquired immune deficiency syndrome (AIDS) telah menjadi pandemi di seluruh dunia. ${ }^{1}$ Kasus AIDS pertama kali dilaporkan di Amerika tahun 1981 pada orang homoseksual dewasa, sedangkan pada anak dilaporkan pertama kali tahun 1982. ${ }^{2,3}$ Pada tahun 1997 infeksi HIV menduduki peringkat ke sebelas penyebab kematian diantara anak usia 1 sampai 4 tahun di Amerika. ${ }^{3}$ Di Afrika merupakan penyebab utama kematian. Data dari Organisasi Kesehatan Dunia, me-

\footnotetext{
Alamat Korespondensi:

Dr. Sjawitri P Siregar, Sp.A(K).

Departemen Ilmu Kesehatan Anak FKUI-RSCM, Divisi AlergiImunologi.

Jl. Salemba 6, Jakarta 10430.

Telepon: 021-316 1144. Fax. 021-3913982.
}

Dr. Boris Januar: PPDS Ilmu Kesehatan Anak FKUI, Jakarta nunjukkan lebih dari 40 juta penduduk dunia terinfeksi HIV /AIDS dan menyebabkan kematian lebih dari 20 juta jiwa. ${ }^{1}$ Di Indonesia sampai akhir bulan September 2002 tercatat 3.374 kasus infeksi $\mathrm{HIV}(+)$, sedangkan kasus AIDS tercatat 957 kasus dan 82 kasus AIDS diantaranya adalah anak berusia di bawah 16 tahun. ${ }^{4}$

Cluster of differentiation $4^{+}\left(\mathrm{CD} 4^{+}\right)$merupakan target utama dari virus HIV, sel ini dapat ditemukan di berbagai jaringan sehingga menyebabkan kelainan multi sistim dengan gejala dan tanda klinis yang bervariasi. $^{5}$

Tujuan sajian kasus ini adalah untuk mendiskusikan masalah diagnosis dan tata laksana infeksi HIV pada bayi.

\section{Kasus}

Bayi perempuan, berusia 5 bulan datang ke Instalasi Gawat Darurat RSCM dengan keterangan prolonged fever. Pasien menderita demam yang sifatnya terus 
menerus dan tidak terlalu tinggi, dan selama ini pasien tidak pernah dibawa berobat. Tiga minggu kemudian pasien menderita kejang disertai demam tinggi, kejang satu kali, merupakan kejang pertama kali, bersifat umum, kelojotan, selama satu menit. Setelah kejang pasien menangis. Pasien kemudian dirawat di rumah sakit H. Pasien mendapat terapi cefotaxim, meropenem, dan terakhir ceftazidime dengan amikasin. Pasien dirujuk ke RSCM karena tidak terdapat perbaikan klinis.

Selama perawatan pasien tetap menderita demam $\left(38^{\circ} \mathrm{C}-40^{\circ} \mathrm{C}\right)$ tetapi tidak didapatkan kejang lagi. Pemeriksaan laboratorium didapatkan $\mathrm{Hb} 9.4 \mathrm{~g} / \mathrm{dL}$, Ht 26,7 vol\%, leukosit $8000 / \mathrm{mL}$, trombosit 313000/ $\mathrm{mL}$, LED $50 \mathrm{~mm} / \mathrm{jam}$, hitung jenis (\%): basofil 0 , eosinofil 1 , batang 0 , segmen 61 , limfosit 37 , monosit 1. Pemeriksaan urinalisis dalam batas normal, SGOT $1800 \mathrm{~m} / \mathrm{L}$, SGPT $440 \mathrm{~m} / \mathrm{L}$. Hasil biakan darah didapatkan kuman Serratia marcescens, sensitif terhadap amikasin, ceftazidime dan trimetoprim. Pemeriksan lumbal pungsi didapatkan sel $3 / \mathrm{mL}$, protein $120 \mathrm{mg} / \mathrm{dL}$, uji protein likuor protein None dan Pandy negatif.

Sejak usia dua bulan pasien sering sakit batuk pilek disertai demam. Riwayat penyakit keluarga, ibu pasien menderita HIV yang diketahui pada saat melahirkan. Ibu pasien sering melakukan hubungan sex bebas dengan berganti-ganti pasangan. Ayah pasien pernah diperiksa serologi dan dikatakan tidak menderita HIV. Pasien merupakan anak tunggal. Selama hamil ibu pasien sering menderita demam disertai sariawan yang terus menerus. Pasien lahir secara bedah kaisar, cukup bulan dan langsung menangis dengan berat lahir $2400 \mathrm{~g}$ dan panjang lahir $46 \mathrm{~cm}$. Saat ini pasien sudah mendapatkan imunisasi BCG, DPT-1 dan polio-1. Sejak lahir pasien tidak mendapat ASI.

Pada pemeriksaan fisis di Instalasi Gawat Darurat RSCM di dapatkan bayi sadar, tidak sesak dan tidak sianosis. Laju nadi $160 \mathrm{x} /$ menit, laju pernafasan $30 \mathrm{x} /$ menit, suhu aksila $39,5^{\circ} \mathrm{C}$. Berat badan $5000 \mathrm{~g}(<\mathrm{P} 5 \mathrm{NCHS})$, panjang badan $62 \mathrm{~cm}$ (P25 NCHS). Kepala bulat, UUB datar, lingkar kepala $39 \mathrm{~cm}$ (normal). Pada pemeriksaan mata, pupil bulat isokor, reflek cahaya normal, gerakan bola mata baik, sklera tidak ikterik, konjungtiva tampak pucat. Pemeriksaan telinga hidung dan tenggorokan (THT) tidak ditemukan kelainan. Teraba pembesaran kelenjar getah bening multiple di daerah leher dan ketiak kanan dan kiri. Dada terlihat simetris tidak didapatkan retraksi, suara napas vesikuler, tidak terdengar ronki maupun mengi, bunyi jantung I-II normal, tidak terdengar bising maupun irama derap. Perut teraba lemas dengan hati $5 \mathrm{~cm}$ di bawah lengkung iga kanan dan $3 \mathrm{~cm}$ di bawah processus xiphoid dengan tepi tajam, kenyal dan permukaan rata. Limpa tak teraba, bising usus normal. Alat gerak akral hangat, perfusi perifer baik dan didapatkan BCG-itis didaerah deltoid atas.

Pemeriksaan laboratorium didapatkan $\mathrm{Hb} 7.7 \mathrm{~g} /$ $\mathrm{dl}$, leukosit $10800 / \mathrm{mL}$, trombosit $440000 / \mathrm{mL}$ dengan hitung jenis (\%): Basofil 0, eosinofil 0, batang 0, segmen 62, limfosit 32, monosit 6. SGOT $108 \mathrm{~m} / \mathrm{L}$, SGPT $111 \mathrm{~m} / \mathrm{L}, \mathrm{CD}^{+}$33\%, Viral Load (VL) PCR RNA 3.034.420 kopi RNA/ml, HIV Elisa reaktif, HIV Dipstik reaktif.

Pemeriksaan foto rontgen dada di dapatkan kardiomegali ringan dan gambaran infiltrat pada kedua lapangan paru. Uji tuberkulin negatif. Hasil konsultasi dengan Sub Divisi Pulmonologi Bagian Ilmu Kesehatan Anak RSCM dikatakan sesuai dengan limfoid interstitialis pneumonitis (LIP). (Gambar 1)

Pasien didiagnosis terinfeksi HIV kategori C tanpa penekanan sistim imun, dan diberikan terapi Zidovudin 4 × $10 \mathrm{mg}$, Lamivudine $2 \times 20 \mathrm{mg}$, tranfusi sel darah merah, trimetophrin sulfametoksasol $2 \times 20$ mg(TMP). Pasien dianjurkan untuk konseling dan kontrol setiap bulan untuk dilakukan pemeriksaan terhadap gejala klinis, darah tepi, fungsi hati dan pemeriksaan $\mathrm{CD}^{+}$setiap tiga bulan.

\section{Diskusi}

Human immunodeficiency virus merupakan golongan retrovirus subkelompok lentivirus. Saat ini dikenal 2 serotipe virus HIV, yaitu HIV-1 dan HIV-2. ${ }^{1,2}$ Serotipe virus HIV-1 dikenal sebagai penyebab utama AIDS di seluruh dunia; sedangkan HIV-2 lebih behubungan dengan simian immunodeficiency virus (SIV) pada simpanse. ${ }^{1}$

Pada awal terjadinya epidemi HIV, transfusi produk darah (faktor pembekuan, trombosit dan plasma) merupakan penyebab tersering infeksi HIV pada anak. Dengan berkembangnya skrining terhadap produk darah, maka penularan virus secara perinatal 


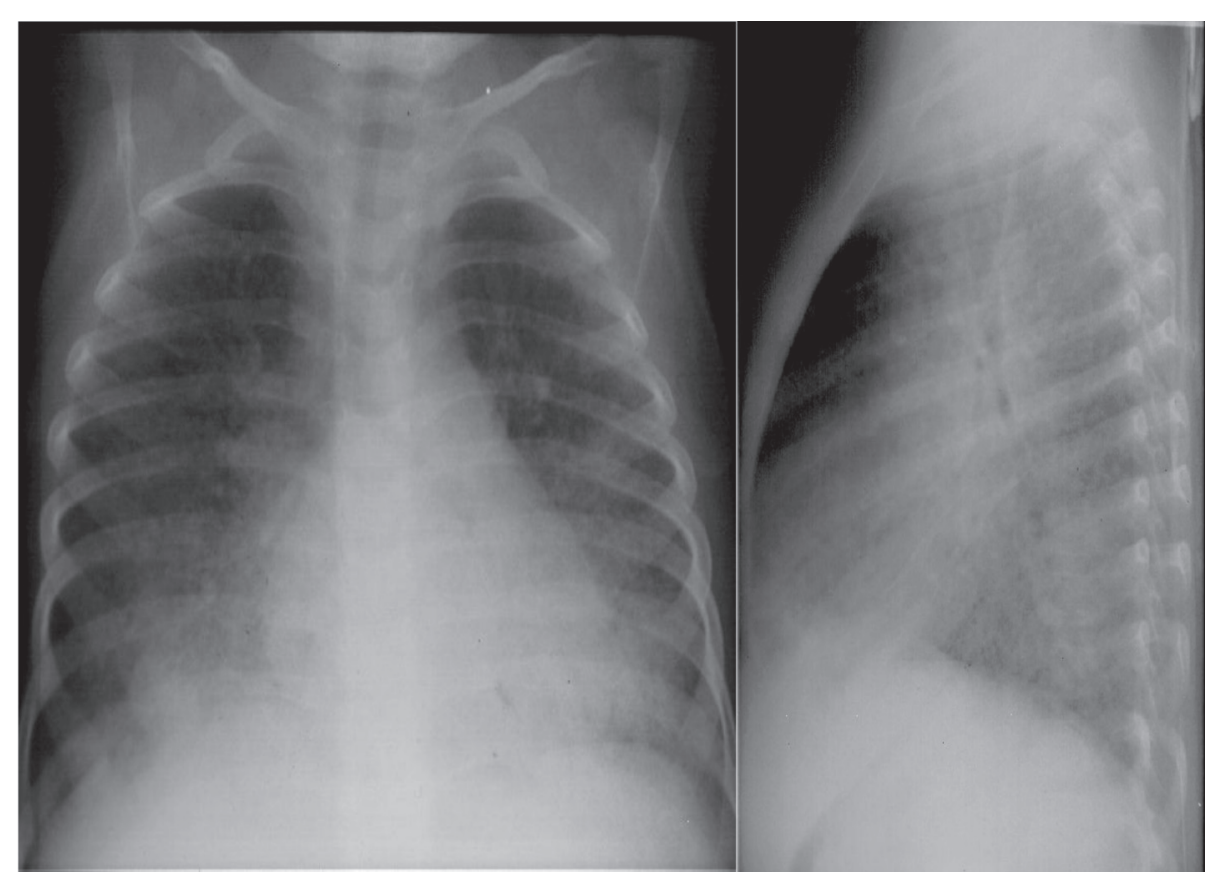

Gambar 1. Limphoid interstitial pneumonitis

menjadi mekanisme penularan HIV pada anak yang tersering ${ }^{1-3,6}$ Bayi yang lahir dari ibu dengan HIV dapat terinfeksi melalui transplasenta pada saat dalam kandungan $(20 \%)$, infeksi perinatal pada saat melahirkan (60-70\%) atau infeksi pasca natal melalui air susu ibu $(15-20 \%)^{1}$. Infeksi HIV pada bayi yang terjadi dalam kandungan biasanya mempunyai gejala klinis yang lebih hebat dan lebih cepat menjadi AIDS dalam 2 tahun pertama dibandingkan dengan bayi yang mengalami infeksi pada saat perinatal ${ }^{3,7}$. Pada kasus ini mengingat timbulnya gejala pada usia 5 bulan, persalinan secara bedah kaisar dan tidak diberikannya ASI maka kemungkinan penularan terjadi pada saat di dalam kandungan.

Pencegahan infeksi HIV pada anak menurut Pediatric AIDS Clinical Trials Group (PACTG) protokol 076 (Februari 1994) dengan pemberian antiretroviral Zidovudine (ZDV) pada ibu HIV positif dan anak, dapat menurunkan angka penularan dari ibu terhadap anak sebesar $25.5 \%$ menjadi $8.3 \%$. Di samping itu bedah kaisar secara elektif dan menghindari pemberian ASI dapat pula menurunkan resiko penularan dari ibu terhadap anak. ${ }^{8-10}$ Pada kasus ini persalinan dilakukan secara bedah kaisar, bayi hanya mendapat PASI tetapi tidak diberikan pencegahan antiretroviral.

Sebelum tahun 1994, test untuk mendeteksi infeksi HIV yang banyak digunakan adalah enzymelinked immunosorbent assay (ELISA) dan Western Blot Test, keduanya mendeteksi IgG spesifik terhadap HIV. Kekurangan pemeriksaan ini tidak dapat dilakukan pada usia dini karena IgG ibu dapat melalui placenta dan masih dapat dideteksi sampai usia 18 bulan. Saat ini sudah terdapat beberapa pemeriksaan penunjang yang dapat mendeteksi infeksi HIV secara dini yaitu tes PCR DNA HIV test, kultur HIV, p24 core antigen level, dan HIV RNA viral level. Tes PCR DNA HIV merupakan pemeriksaan yang direkomendasikan untuk skrining bayi yang lahir dari ibu HIV (+), pemeriksaan ini mempunyai sensitivitas sebesar $83 \%$ jika pemeriksaan dilakukan pada usia 48 jam, sensitivitas ini tidak banyak berubah selama usia satu minggu tapi kemudian sensitivitas menjadi $93 \%$ pada usia dua minggu. Pemeriksaan ini sebaiknya dilakukan sebelum bayi berusia 48 jam dan pemeriksaan diulang ketika bayi berusia 1-2 bulan dan usia 4-6 bulan jika hasil pemeriksaan awal memberikan hasil negatif., 10

Kultur HIV mempunyai sensitivitas yang sama dengan PCR DNA HIV tetapi pemeriksaan ini lebih mahal, lebih kompleks dan hasil baru didapatkan setelah 2-4 minggu. Pemeriksaan lain seperti level antigen p24 dan HIV RNA viral mempunyai sensitivitas yang lebih rendah ${ }^{7,11}$. 
Diagnosis pasti infeksi HIV ditegakkan apabila dua kali pemeriksaan virologi positif dengan selang waktu 1 bulan. Bayi dikatakan 95\% tidak menderita infeksi HIV jika didapatkan hasil negatif pada tiga kali pemeriksaan virologi (saat lahir, usia satu bulan dan usia 4 bulan) didapatkan hasil negatif. Secara pasti dapat dikatakan bayi tidak terinfeksi HIV jika pemeriksaan HIV specific IgG assay (ELISA) pada usia 18 bulan memberikan hasil negatif. ${ }^{10}$

Pada tahun 1994 Centers for Disease Control and prevention membuat revisi klasifikasi infeksi HIV pada anak kurang dari 13 tahun berdasarkan 3 kategori yakni ; 1) Status infeksi HIV, 2) Status klinis, 3) Status imun. Seorang anak yang telah diklasifikasikan dalam satu kategori tidak dapat diklasifikasikan kembali kekategori yang lebih ringan, meskipun gejala klinis dan status imun mengalami perbaikan. ${ }^{5}$ (Tabel 1, Tabel 2 dan Tabel 3)

Kasus ini termasuk dalam klasifikasi terinfeksi HIV, kategori $C$, tidak ada penekanan sistim imun berdasarkan HIV RNA PCR (+), gejala klinis berupa demam lebih dari 1 bulan, BCG-itis, hepatomegali, limfadenopati, LIP, gizi kurang dan anemia serta persentase $\mathrm{CD}^{+} 33 \%$.

Pemantauan prognosis anak dengan infeksi HIV dapat melalui gejala klinis, parameter imun dan HIV RNA. ${ }^{7} 12$ Penurunan CD $4^{+}$berhubungan dengan progresifitas infeksi $\mathrm{HIV}, \mathrm{CD}^{+}$yang rendah mempunyai prognosi yang buruk. Pemantauan status imun sangat penting dalam menatalaksana bayi dan anak dengan infeksi HIV, maka $\mathrm{CD}^{+}$ sebaiknya diperiksa sesegera mungkin setelah hasil virologi HIV positif dan diulang setiap 3 bulan. Kadar $\mathrm{CD}^{+}$juga berguna dalam menentukan pengobatan antiretrovirus dan profilaksis terhadap pneumonia pneumocystis carinii (PCP) setelah anak usia 1 tahun. $^{7}$

HIV RNA viral load yang tinggi juga berhubungan dengan progresitas penyakit. HIV RNA secara umum mempunyai kadar paling rendah pada saat lahir $(<10.000 \mathrm{kopi} / \mathrm{ml})$ dan meningkat mencapai nilai yang tinggi pada usia 2 bulan sampai usia 1 tahun $(>100,000$

Tabel 1. Klasifikasi berdasarkan status infeksi HIV ${ }^{11}$

\begin{tabular}{|c|c|}
\hline Infeksi HIV: & $\begin{array}{l}\text { - Anak usia < } 18 \text { bulan lahir dari ibu HIV }(+) \text { dan terbukti positif pada dua kali pemeriksaan yang berbeda } \\
\text { dengan HIV kultur, HIV PCR, HIV antigen (p24) atau dijumpai kriteria AIDS } \\
\text { - Anak usia > } 18 \text { bulan lahir dari ibu HIV }(+) \text { atau anak terinfeksi oleh darah, produk darah dimana HIV } \\
\text { antibodi positif dengan ELISA dan Western blot atau dijumpai kriteria AIDS }\end{array}$ \\
\hline \multicolumn{2}{|c|}{$\begin{array}{c}\text { Perinatally exposed: anak yang tidak termasuk dalam kriteria diatas, HIV }(+) \text { secara ELISA pada anak }<18 \text { bulan atau tidak } \\
\text { diketahui status antibodi tetapi lahir dari ibu } \operatorname{HIV}(+)\end{array}$} \\
\hline Seroreverter: & $\begin{array}{l}\text { Anak yang lahir dari ibu HIV(+), antibodi HIV negatif setelah dua kali pemeriksaan pada usia 6-18 bulan, } \\
\text { atau satu kali negatif secara ELISA pada usia }>18 \text { bulan dan tidak didapatkan AIDS. }\end{array}$ \\
\hline
\end{tabular}

Tabel 2. Klasifikasi infeksi HIV berdasarkan gambaran klinis ${ }^{5,711}$ (lanjutan)

Keadaan kondisi klinis yang termasuk dalam kategori C untuk anak terinfeksi HIV adalah:

- Infeksi bakteri serius, multiple atau berulang yang dikonfirmasi

- Coccidioidomycosis

- dengan paling sedikit dua hasil kultur dalam dua tahun.

- Kandidiasis esofagus atau pernafasan (bronkus, trachea, paru)

- Cryptosporidiosis atau Isosporiasis dengan diare persisten > 1 bulan.

- CMV dengan masa timbul gejala pada usia > 1 bulan, dilokasi selain hati, limpa atau kelenjar limfe.

- Infeksi virus Herpes simplex yang menyebabkan ulkus mukokutan selama $>$ 1bulan

- Mycobacterium tuberkulosis yang menyebar atau ektrapulmonal Salmonella (nontifoid)

- Toksoplasma di otak dengan masa timbul pada usia > 1bulan

- Cryptococcosis ekstra pulmonal

- Ensefalopati

- Histoplasmosis

- Sarkoma kaposi

- Lymphoma primer di otak

- Mycobactrium avium complex

- Pneumocystis carinii pneumonia

- Progresif multifocal

- Septikemia karena leukoencephalopathy

- Wasting syndromel failure to thrive 
Sari Pediatri, Vol. 6, No. 1, Juni 2004

Tabel 2. Klasifikasi infeksi HIV berdasarkan gambaran klinis, 5,711

Kategori N : $\quad$ Anak tanpa gejala infeksi HIV atau hanya 1 gejala pada kategori A

Asimtomatik

Kategori A:

Gejala ringan

Kategori B :

Gejala sedang
Anak dengan 2 gejala atau lebih dibawah ini tetapi tanpa gejala kategori B dan C

- Limfadenopati

- Hepatomegali

- Dermatitis

- Splenomegali

- Infeksi saluran nafas atas rekuren, sinusitis atau otitis media

- Anemia, netropenia,trombositopeni menetap $\geq 30$ hari

- Meningitis bakteri, pneumonia, sepsis

- Kandidiasis orofaring $>2$ bulan, anak $>6$ bulan

- Kardiomiopati

- Infeksi CMV sebelum usia 1 bulan

- Diare kronik atau rekuren

- Hepatitis

- HSV stomatitis rekuren lebih dari 2 episode dalam 1 tahun

- Varisela

Kategori C : Gejala berat: sesuai dengan definisi AIDS kecuali LIP
- HSVbronkitis pneumonitis, atau esofagitis sebelum usia 1 bulan

- Herpes zoster > 2 episode dalam 1 tahun

- Leiomiosarkoma

- LIP (lymphoid interstitial pneumonia)

- Nefropati

- Nokardiosis

- Demam lebih dari 1 bulan

- Toksoplasmosis, sebelum usia 1 bulan

Tabel 3. Klasifikasi infeksi HIV berdasarkan sistim imun $\left(\mathrm{CD}^{+}\right) .{ }^{11}$

\begin{tabular}{|c|c|c|c|c|c|c|}
\hline \multirow{3}{*}{ Kategori imun } & \multicolumn{6}{|c|}{ Umur } \\
\hline & \multicolumn{2}{|c|}{$<12$ bulan } & \multicolumn{2}{|c|}{$1-5$ tahun } & \multicolumn{2}{|c|}{ 6-12 tahun } \\
\hline & $\mathrm{no} / \mathrm{mm}$ & $\%$ & $\mathrm{no} / \mathrm{mm}^{3}$ & $\%$ & no. $/ \mathrm{mm}^{3}$ & $\%$ \\
\hline Kategori 1 & & & & & & \\
\hline $\begin{array}{l}\text { Tanpa supresi } \\
\text { Kategori } 2\end{array}$ & $\geq 1,500$ & $(\geq 25 \%)$ & $\geq 1000$ & $(\geq 25 \%)$ & $\geq 500$ & $(\geq 25 \%)$ \\
\hline $\begin{array}{l}\text { Supresi sedang } \\
\text { Kategori } 3\end{array}$ & 750-1,499 & $(15-24 \%)$ & 500-999 & $(15-24 \%)$ & $200-499$ & $(15-24 \%)$ \\
\hline Supresi berat & $<750$ & $(<15 \%)$ & $<500$ & $(<15 \%)$ & $<200$ & $(<15 \%)$ \\
\hline
\end{tabular}

kopi/ml sampai 10 juta kopi/ml ) kemudian menurun secara perlahan. Pada anak usia $<1$ tahun sangat sulit untuk menginterpretasikan progresitas penyakit dengan HIV RNA kopi saja. ${ }^{7}$ Pada kasus ini didapatkan $\mathrm{CD}^{+}$sebesar $33 \%$, dengan HIV RNA viral load sebesar $3.034 .420 \mathrm{kopi} / \mathrm{ml}$.

Sebelum memulai terapi antiretrovirus sebaiknya dilakukan konseling terhadap orang tua, pengasuh dan pasien (jika usia memadai) mengenai pentingnya ketaatan dalam menggunakan obat dan resiko dari ketidak taatan penggunaan obat.
Indikasi untuk memulai pengobatan antiretrovirus pada anak dengan infeksi HIV dapat dilihat pada Tabel $4 .^{7}$

Pengobatan tunggal saat ini tidak lagi dianjurkan untuk mengobati infeksi HIV. Penggunaan zidovudin sebagai obat tunggal hanya digunakan pada bayi tersangka HIV selama usia 6 minggu pertama untuk mencegah penularan HIV perinatal. ${ }^{7}$ Berdasarkan data klinis, imunologi dan virologi dari percobaan klinis pada orang dewasa dan anak, regimen obat antiretrovirus dikelompokan dalam sangat dianjurkan, 
dianjurkan sebagai alternatif dan dianjurkan pada keadaan khusus. Pengobatan antiretrovirus pada bayi, anak dan remaja dianjurkan berupa pengobatan kombinasi. Pengobatan kombinasi ini mempunyai keuntungan dibandingkan pengobatan tunggal yaitu progresitas penyakit lebih lambat, respon virologi dan

Tabel 4. Indikasi pengobatan antiretrovirus pada infeksi HIV anak ${ }^{7}$

- Gejala klinis yang berhubungan dengan infeksi HIV (kategori klinik A,B, atau C).

- Terdapat bukti penekanan imun yang di indikasikan dengan jumlah dan persentase CD4+ (kategori imun 2 atau 3).

- Usia < 12 bulan, tanpa memperhatikan klinis, imunologi atau status virologi.

- Untuk anak usia ${ }^{3} 1$ tahun tanpa gejala dengan status imun normal, terdapat dua alternatif yang dapat dipertimbangkan Alternatif 1: Memulai terapi - tanpa memperhatikan status usia dan gejala

Alternaif 2: Menunda pengobatan apabila risiko progresitas penyakit klinis rendah

Faktor yang perlu dipertimbangkan untuk pemberian pengobatan

- Peningkatan jumlah HIV RNA

- Penurunan dari jumlah dan persentase CD4+ (kategori imun 2)

- Terdapat perburukan dari gejala klinis

Tabel 5. Regimen antiretrovirus yang dianjurkan untuk pengobatan awal infeksi HIV pada anak

\section{Sangat dianjurkan}

Terbukti secara uji klinis mempunyai keuntungan klinis dan atau penekanan terhadap replikasi HIV pada dewasa dan/atau anak.

- Satu kali dosis tunggal protease inhibitor aktif ( nelfinavir atau ritonavir) ditambah 2 nukleosida analog reverse transcriptase inhibitor. Kombinasi dua NRTI yang dianjurkan yaitu kombinasi ZDV dan ddI, ZDV dan lamivudin (3TC), serta stavudine (d4T) dan ddI.

- Untuk anak yang dapat menelan kapsul diberikan non nukleosida reverse transkriptase inhibitor (NNRTI) efavirenz (sustivaÒ) ditambah dua NRTIs atau efavirenz (sustivaO) ditambah nelfinavir dan satu NRTI

Dianjurkan sebagai alternatif

Terbukti secara uji klinis dapat menekan replikasi HIV, namun

1. Mempunyai daya tahan lebih rendah pada dewasa dan/atau anak dibandingkan dengan regimen sangat dianjurkan.

2. Terbukti efeksitas tidak lebih banyak dibandingkan konsekuensi reaksi sampingnya (misalnya, toksisitas, interaksi obat, harga, dan lain-lain )

3. Pengalaman pada bayi dan anak masih terbatas

- NVP dan dua NTRIs

- $\quad$ ABC dgn kombinasi ZDV dan 3 TC

- Lopinavir / ritonavir dgn dua NRTIs atau satu NRTI dan NNRTI

- IDV atau SQV soft gel kapsul dgn dua NRTIs utk anak yg dapat menelan kapsul

Dianjurkan hanya untuk keadaan khusus

Terbukti secara uji klinis

1. Penekanan terhadap virologi lebih kurang dibandingkan kelompok sangat dianjurkan atau kelompok alternatif

2. Data mengenai ini masih permulaan dan belum dapat disimpulkan untuk penggunaan terapi awal tetapi cukup beralasan digunakan pada keadaan khusus

- Dua NRTIs

- APV kombinasi dengan NRTIs atau ABC

Tidak dianjurkan

Bukti tidak digunakan karena dapat timbul potensiasi terhadap toksisitas atau tidak baik terhadap virologi.

- Monoterapi

- ddC dan ddI

- $\quad \mathrm{ddC}$ dan $\mathrm{d} 4 \mathrm{C}$

- d4T dan ZDV

- $\mathrm{ddC}$ dan 3TC 
imunologi lebih baik, mencegah resisten obat. ${ }^{7}$

Sampai Februari 2001, terdapat 15 obat antiretrovirus yang diakui untuk digunakan pada infeksi HIV dewasa dan remaja, dan 11 diantaranya di indikasikan untuk pengobatan pada anak. Obat antiretrovirus dikelompokkan menjadi a) Nucleoside analogue reverse transciptase inhibitors (NRTIs), b) Nonnucleoside analogue reverse transcriptase inhibitors

Tabel 7. Jadwal imunisasi yang dianjurkan pada anak yang terinfeksi HIV.

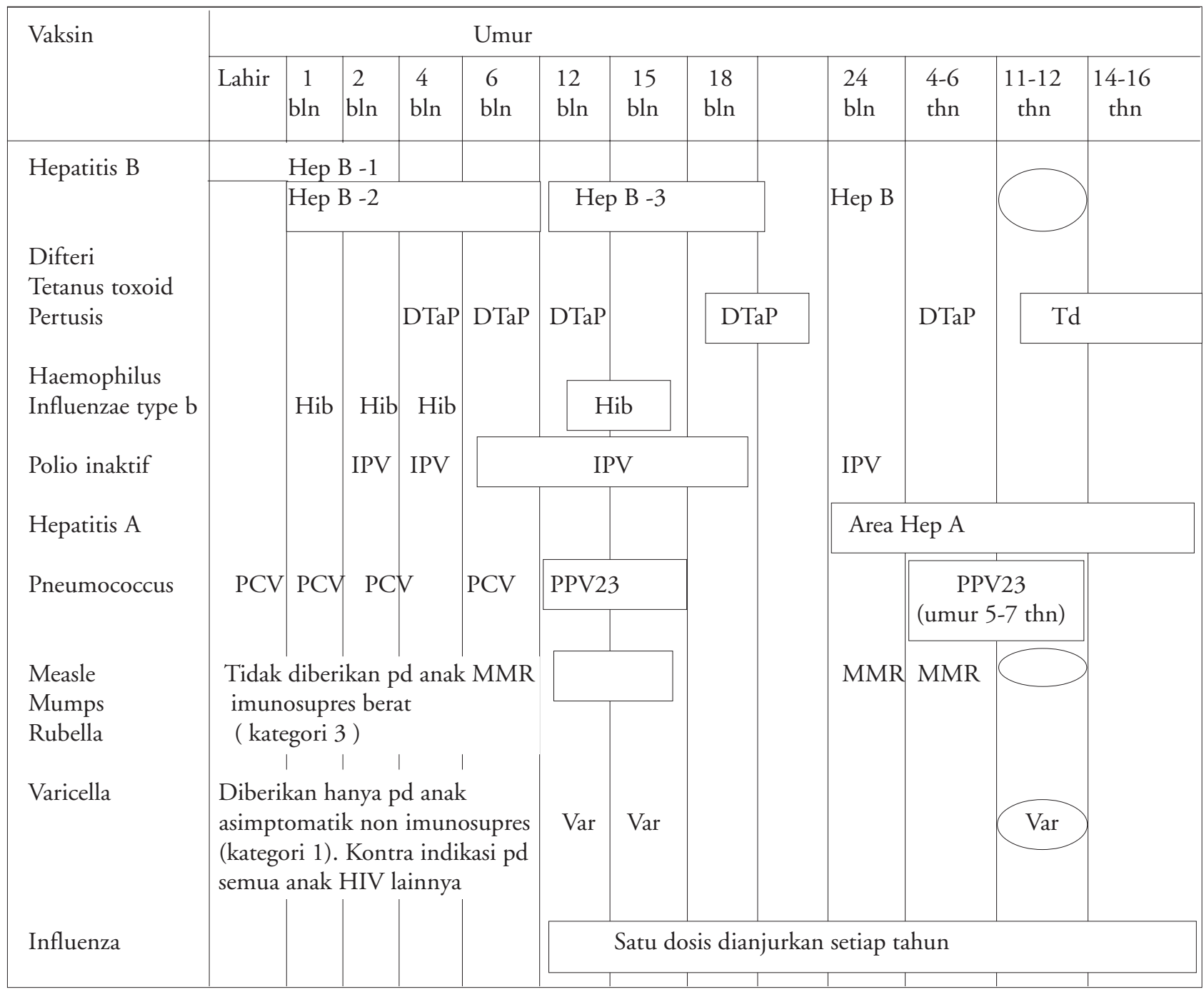

\footnotetext{
Range umur yang dianjurkan untuk vaksinasi

Vaksinasi diberikan bila dosis anjuran sebelumnya terlewatkan atau diberikan lebih awal dari usia minimal
yang dianjurkan $\ldots \ldots \ldots$

: $\quad$ Dianjurkan pada keadaan tertentu
}

Hep B; vaksin Hepatitis B, DTaP; vaksin Diphtheria tetanus toksoid and acellular pertussis vaksin, HiB; Haemophilus influenzae B, Td; Tetanus and diphtheria toxoids, IPV; inactivated poliovirus, Hep A; Hepatitis A n, PCV; vaksin pneumococcal conjugate, PPV23; 23 valent pneumoccal polysaccarida, MMR; Measles mumps rubbela, Var; Varicella zoster virus. 
(NNRTIs), c) Protease Iinhibitors (PIs)., ${ }^{72}$

Obat-obat yang termasuk kelompok NRTIs yaitu abacavir (ABC), didanosine (ddI,videxâ), lamivudine (3TC,Epivirâ), stavudine (d4T, Zeritâ), zalcitabine (ddC, HIVIDâ), zidovudine (ZDV, AZT, Retrovirâ), yang termasuk kelompok NNRTIs yaitu delavirdine (DLV, Rescriptorâ), efavirenz (EFV, Sustivaâ), nevirapine (NVP, viramuneâ), dan yang termasuk kelompok PIs yaitu amprenavir (APV, Ageneraseâ), indinavir (IDV, crixivanâ), lopinavir/ritonavir (LPV/RTV), nelfinavir (NFV, Viraceptâ), ritonavir (RTV, Novirâ), saquinavir (SQV). ${ }^{7,12,13}$ Obat yang tersedia di Pokdisus AIDS FKUI adalah zidovudin, lamivudin, stavudin, nevirapin dan nelfinavir. Regimen antiretrovirus yang direkomendasikan untuk pengobatan awal infeksi HIV pada anak pada Tabel 5. Pada kasus ini pengobatan antiretrovirus yang diberikan adalah kombinasi ZDV dan 3TC, karena kedua obat ini terdapat di Pokdisus AIDS FKUI, nelfinavir (NFV) tidak diberikan mengingat efek toksis terhadap hati.

Berdasarkan Pediatric Spectrum of Disease Study beberapa infeksi oportunistik sering terjadi pada anak dengan infeksi HIV, yaitu pneumocystis carinii pneumonia (PCP) umumnya timbul pada usia 3 sampai 6 bulan, Mycobacterium avium complex (MAC) sering terjadi pada anak usia 5 tahun, candidiasis esofagus, infeksi bakterial berulang, dan tuberculosis. ${ }^{3}$ (Tabel 6) Pencegahan terhadap infeksi oportunistik dibagi dalam pencegahan primer dan pencegahan sekunder. Pencegahan primer yaitu mencegah terjadinya infeksi, sedangkan pencegahan sekunder yaitu pemberian obat setelah infeksi terjadi. ${ }^{13}$

Pencegahan terhadap infeksi oportunistik dapat dihentikan apabila terdapat peningkatan dari $\mathrm{CD}^{+}$ $>200 / \mathrm{mL}$ selama ${ }^{3} 3$ bulan. ${ }^{13,14}$

Anak dengan infeksi HIV sebaiknya diberi imunisasi sesegera mungkin dengan vaksin inactivated sedangkan imunisasi dengan menggunakan vaksin hidup attenuated pada anak dengan infeksi HIV perlu dilakukan secara hati-hati, dan sebaiknya tidak diberikan apabila di dapatkan penekanan sistim imun atau gejala klinis infeksi HIV. ${ }^{10,15}$

Jadwal imunisasi yang dianjurkan untuk bayi terinfeksi HIV tertera pada Tabel 7. Pada kasus ini pemberian imunisasi tidak tepat karena diberikan vaksin hidup sebelum diketahui status imunitasnya.

\section{Daftar Pustaka}

1. Sleasman JW, Goodenow MM. HIV-1 infection. J Allergy Clin Immunol 2003; 111:S582-92.

2. Matondang CS. AIDS pada anak. Dalam: Akib AP, Matondang CS, penyunting. Buku Ajar alergi-imunologi anak. Jakarta: Balai Penerbit FKUI 1996; 274-86.

3. Lindegren ML, Steinberg SMS, Byers RH Jr. Epidemiology of HIV/AIDS in children. Pediatr Clin North Am 2000; 47:1-20.

4. Direktorat Jenderal Pemberantasan Penyakit Menular dan Penyehatan Lingkungan. Data laporan pengidap infeksi HIV dan kasus AIDS, 30 September 2002. Departemen Kesehatan Republik Indonesia 2002.

5. Abuzaitoun OR, Hanson IC. Organ-specific manifestations of HIV disease in children. Pediatr Clin North Am 2000; 47:109-24.

6. Matondang CS. AIDS pada anak pada masa mendatang. Pidato pngukuhan Guru Besar FKUI 1992: 1-23.

7. The Working Group on antiretroviral and medical management of HIV-infected children, The National Resources and Services Administration, and The National Institute of Health. Guidelines for the use of antiretroviral agents in pediatric HIV infection. December 14, 2001. Diperoleh dari http://www.aidsinfo.org

8. Bulterys M, Fowler MG. Prevention of HIV infection in Children. Pediatr Clin North Am 2000; 47: 241-60.

9. Perinatal HIV Guidelines Working Group. U.S. Public Health Service Task Force recommendation for the use of antiretroviral drugs in pregnant women infected with HIV-1 for maternal health and for reducing perinatal HIV-1 transmission in the United States, February 25, 2000. Diperoleh dari http://www.aidsinfo.org.

10. Krist AM, Faucher AC. Management of newborns exposed to maternal HIV infection. Am Fam Physician 2002;65: 2049-56,2061.

11. Caldwell MB, Oxtoby MJ, Simonds RJ, Lindegren ML, Rogers MF. 1994 Revised classification system for human immunodeficiency virus infection in children less than 13 years of age. September 30, 1994. Diperoleh dari http://www.aidsinfo.org.

12. Rossum AMC, Fraaij PLA, Groot R. Efficacy of highly active antiretroviral therapy in HIV-1 infected children. Lancet Infectious Diseases 2002;2:124-36.

13. Djauzi S, Djoerban Z. Penatalaksanaan HIV/AIDS di pelayanan kesehatan dasar. Jakarta: Balai penerbit Fakultas Kedokteran Universitas Indonesia, 2002. 1-71.

14. U.S. Public Health Service (USPHS) and Infection Disease Society of America. 2001 USPHS/IDSA guideline 
Sari Pediatri, Vol. 6, No. 1, Juni 2004

for the prevention of opportunistic infection in persons infected with Human Immunodeficiency Virus, November 28, 2001. Diperoleh dari http://www.aidsinfo.org.

15. American Academy of Pediatrics. Human immunodefi- ciency virus infection. Dalam: Pickering LK, penyunting. 2000 Red Book: report of the Committee on infectious diseases. Edisi 25. Elk Grove Village, IL. American Academy of pediatric2000;325-50. 